\title{
Dual Archivist/Librarians: Balancing the Benefits and Challenges of Diverse Responsibilities
}

\section{Mary Manning and Judy Silva}

\begin{abstract}
A survey of college and university archivists revealed that their roles and responsibilities are broad and diverse. Archival responsibilities have expanded across the board. For the purposes of this study, survey respondents were divided into two groups: archivists with and archivists without library responsibilities. Archivists with library responsibilities, or dual archivist/librarians, commented on a range of responsibilities that they find both beneficial and challenging. These dual archivist/librarians' roles and responsibilities are the focus of this study.
\end{abstract}

\section{Definitions for this Study}

Archivist: For our study, the term "archivist" refers to any information professional whose responsibilities include “appraising, acquiring, arranging, describing, preserving, and providing access to records of enduring value, according to the principles of provenance, original order, and collective control to protect the materials' authenticity and context."1 See appendix: question 1 .

Study pool: The survey respondents included in our study are self-identified archivists (as defined above) who are currently employed at a college or university in the United States. They are from small (1,000-2,999 BA/BS students), medium (3,000-9,999 BA/BS students), or large $(10,000+$ BA/BS students) four- year schools as defined by the Carnegie Foundation. Our two comparison groups within the study pool are archivists with library responsibilities and archivists without library responsibilities.

Dual archivist/librarians: This group consists of archivists (as defined above) who indicated that they also have library responsibilities (see appendix: question 21). ${ }^{2}$ For this survey, library responsibilities are identified as special collections librarianship, library liaison to teaching departments, library instruction, library reference, and/or library collection development.

Archivists without library duties: This comparison group consists of archivists who do not have library responsibilities as defined for this study.

Mary Manning is Assistant University Archivist, DiSC Digital Collections Coordinator in Cushing Memorial Library and Archives at Texas AEM University; e-mail: mmanning@tamu.edu. Judy Silva is Arts Librarian \& Archivist of the Slippery Rock University Archives at Slippery Rock University of Pennsylvania; e-mail: judith.silva@sru.edu. The authors wish to thank Stan Bogdanov and Michael L. Maciel for their assistance with statistical analysis and data representation. We also want to thank our survey testers and our peer readers. (C) Mary Manning and Judy Silva 


\section{Introduction}

This survey-based article examines the contemporary roles and responsibilities of college and university archivists in the United States. It outlines both benefits and challenges identified by survey respondents, all employed as academic archivists, to having nonarchival responsibilities, specifically library responsibilities.

In reviewing survey results, the authors found that just over half of the qualified respondents, 150 of 296 (51\%), were archivists with library duties. While most respondents indicated a wide range of responsibilities, this group of dual archivist/ librarians identified a substantially wider range of duties and responsibilities than other survey respondents. This article focuses on these dual archivist/librarians, outlining both benefits and challenges associated with having such varied and expansive roles. For comparison purposes, the 49 percent of respondents without library duties are also evaluated. This study outlines the scope of responsibilities of these two groups of archivists, focusing on the benefits and challenges cited by those archivists whose nonarchival responsibilities include library duties.

\section{Literature Review}

Keeping in mind that dual archivist/ librarians face, at minimum, the same challenges as other academic archivists, an overview of the expanding and evolving archives profession is a good place to start.

Surveys conducted over the years have documented the changing archives profession. ${ }^{3}$ Frank Boles refers to this phenomenon in his 2010 presidential address to the Society of American Archivists: "We are, after all, not being asked to adjust to a few minor changes in bureaucratic procedure, but rather to make informed decisions on the impact of a radical shift in recording media on the entire profession, from theory to practice, and do it in an incredibly short period of time, on-the-fly, while we attend to all the things we already do." ${ }^{4}$

Christopher Prom and Ellen Swain note that, "Accountability requirements, institutional assessment, the digital revolution, technical standards, changing education requirements for job entry, and increased user expectations shape our current experience." ${ }^{5}$ They suggest that archivists must "develop proactive, innovative, and collaborative approaches ... to fulfill their institutional missions." ${ }^{\prime 6}$

Core archival activities endure amidst evolving responsibilities. Prom reminds us that processing "is at the heart of archival work." ${ }^{\prime 7}$ The persistence of traditional challenges of staffing, workload, and backlog are also noted by Dennis Meissner and Mark A. Greene in their landmark article and the articles it inspired. ${ }^{8}$ Core archival activities are compounded, in some ways, by technology. Encoded Archival Description (EAD) represents a relatively new and increasingly essential skill for many archivists. ${ }^{9}$

Helen Tibbo, Richard Cox, and others discuss the effects of computing and electronic records on basic archival functions, as archivists deal not only with the preservation of electronic records but also with their appraisal, access, and reference issues. ${ }^{10}$ What have become requisite contemporary archival proficiencies are detailed in New Skills for a Digital Era and numerous handbooks. ${ }^{11}$

Many other responsibilities and activities, also featured in the literature, compete for contemporary archivists' time and attention. The archival literature encourages archivists to become involved with a plethora of activities including digitization projects, ${ }^{12}$ oral history programs ${ }_{,}^{13}$ institutional repositories, ${ }^{14}$ records management, ${ }^{15}$ preservation, ${ }^{16}$ disaster preparedness, ${ }^{17}$ archival reference, ${ }^{18}$ and documenting student life, underrepresented groups, and diverse populations. ${ }^{19}$ These programs and activities benefit collection development, user service, and outreach. They allow archivists to better care for their collections and to become involved in activities with shared responsibilities such as institutional repositories and records management. 
Much has also been written in recent years about archival instruction and information literacy - not only teaching with archives but teaching about archives. ${ }^{20}$ Academic archivists are encouraged to go beyond undergraduate instruction to target elementary and high school students, traditional scholars, and the general public. ${ }^{21}$ These authors argue that archival education fulfills a basic research need and allows archivists to have a greater impact outside of the archives. ${ }^{22}$

Outreach takes other forms in the archival literature as well, such as attendance at alumni events and the creation of targeted exhibits to build relationships with potential donors and patrons. ${ }^{23} \mathrm{Ar}-$ chivists are encouraged to get out of the archives and promote the resources in their care, with authors like Tamar Chute noting that outreach may increase donations and the use of archives. At the same time, she cautions against spending too much time on outreach and warns that "it could be a lot of work without monetary or other benefits that the archivist can see right away." ${ }^{24}$

\section{Additional Responsibilities of Dual Archivist/Librarians}

Most of the aforementioned activities cited from the archival literature are addressed in the authors' survey and the resulting study. Many and varied though these activities are, they represent only a portion of the responsibilities held by dual archivist/librarians, which, for the purposes of this study, include special collections librarianship, library liaison to teaching departments, library instruction, library reference, and/or library collection development.

While much has been written about the evolving nature of archivists' roles, virtually nothing has been published in the archives or library literature about information professionals with both library and archives duties. Many dual archivist/librarians are special collections librarians who manage book, manuscript, and archival collections. The journal most closely associated with special collections librarianship is RBM: A Journal of Rare Books, Manuscripts, and Cultural Heritage. $R B M$ covers issues included in other sections of this literature review such as using primary resources in the classroom, digitization, special collections in the digital age, cataloging, backlogs and hidden collections, and preservation, yet it concentrates on rare book collections rather than on archival issues. The journal does, however, have an issue devoted to the convergence of libraries, archives, and museums. ${ }^{25}$ While authors note the common goals of these organizations to preserve and make accessible cultural artifacts for educational or research purposes, many comment on the different levels and means of providing access to collections. ${ }^{26} R B M$ best highlights the convergence of library and archives duties in its discussions of special collections education, noting the importance of both archival and library professional organizations in providing education for special collections scholars. ${ }^{27}$

A 2008 profile in College $\mathcal{E}$ Research Libraries News describes another type of merged position: a catalog librarian/ archivist. The interviewee is quoted as saying, “[T]hey weren't really expecting to find someone with experience in both areas, so the fact that I didn't have archives experience wasn't necessarily a negative." ${ }^{28}$ Our study indicates that, on the contrary, these dual positions are quite common and not merely in special collections. The lack of experience or training for such wide-ranging responsibilities is therefore indeed a negative, and the lack of discussion on dual archivist/ librarian positions is both surprising and troubling.

Janie Mathews and Harold Pardue investigate the presence of information technology skill sets in librarian position announcements; Cox and Riggs both write about required skills for academic archivist positions. ${ }^{29}$ But what about the skills for the range of duties of combined archivist/librarian positions? 
Tom Nesmith raises the question, "What will the archivist need to know in the twenty-first century?" ${ }^{30}$ Indeed, a tremendous amount has been written over the years on educational requirements for archivists. ${ }^{31}$ The pros and cons of situating graduate archival studies within history or library science programs have been argued as well. ${ }^{32}$ Still, the combination of archival and library job responsibilities into one position is not adequately addressed in the contemporary archives and library literature.

There was discussion in the late 1970s and 1980s about archivists and librarians having a common mission. In 1989, David Murrah wrote: “To succeed in today's complex world, the archivist needs the skills ... and technical components of each discipline to be a well-rounded professional." ${ }^{33}$ In today's highly technical environment, where the work of information professionals has expanded exponentially, the stakes are much higher and the range of responsibilities is even greater. A closer look at current roles and responsibilities is therefore in order. This was the motivation for the authors' survey and this resulting study on the responsibilities of dual archivist/librarians.

\section{The Survey}

This article is based on the results of a survey entitled "Defining the Role of Contemporary Archivists at American Colleges and Universities" (see appendix). ${ }^{34}$ Delivered via Survey Monkey, it was distributed through the Society of American Archivists' hosted Archives and Archivists discussion list in November 2009. ${ }^{35}$ While surveys delivered via e-mail listservs admittedly have limitations, the response rate (over 300 total) was deemed sufficient to generate a snapshot of contemporary archivists' responsibilities, and the comments were revealing in detailing benefits and challenges, particularly those of dual archivist/librarians.

The survey was designed to identify how archival collections at colleges and universities in the United States are ad- ministered and to quantify the roles of contemporary archivists in these settings. While the original hypothesis was that institution size was a key factor in determining an archivist's range of responsibilities, a broad summary of responsibilities was the survey's principal aim. The authors also hoped to document any benefits and challenges related to having nonarchival responsibilities.

The survey targeted academic archivists specifically and included questions addressing job titles, definitions of primary roles, institution size, and the administrating unit for the archives program. Other questions focused on archival and nonarchival responsibilities including, but not limited to, library responsibilities.

Not until responses were analyzed did the picture of dual archivist/librarians fully materialize and the issues of this group of academic archivists come into focus. While the survey did address library responsibilities, it did so in the broader context of nonarchival responsibilities. A sharper distinction between responsibilities in the main library, special collections, and other areas would have engendered greater specificity about library duties. Records management, institutional repositories, tenure, research, and scholarly writing responsibilities were also addressed. The survey was conducted anonymously and included numerous opportunities for comments.

\section{Methodology}

Our study pool included only archivists currently employed at small, medium, and large four-year colleges and universities in the United States. We analyzed the results of two groups of survey respondents: dual archivist/librarians and archivists without library responsibilities. In the process, the authors observed a divergence between these groups and their members' perceptions about benefits and challenges encountered in fulfilling their job duties.

The quantitative analysis section of this article presents survey findings related to job responsibilities-archival, 
library, and other nonarchival responsibilities-comparing the responsibilities of the two groups. The qualitative analysis section references dual archivist/ librarians' survey responses to questions about challenges and benefits to having nonarchival responsibilities, particularly library duties. Responses in this section were analyzed with a tagging methodology using ATLAS.ti software.

\section{Research Findings: Analysis of Quantitative Data}

Survey results indicate that college and university archivists in the United States have diverse duties. Of the over 300 survey respondents, 296 qualified for the study pool. The majority of the study pool, 231 archivists or $78 \%$, have nonarchival responsibilities.

One hundred fifty qualified respondents, $51 \%$ of the study pool, are archivists who also have nonarchival duties that include library responsibilities: dual archivist/librarians. The job responsibilities of this group are examined in this study and are broken into three groups: archival, nonarchival, and library-related responsibilities. This group's responses are measured against the archivists without library responsibilities (146 qualified respondents or $49 \%$ of the study pool). This comparison group includes respondents with nonarchival responsibilities other than library-related and respondents without any nonarchival responsibilities.

\section{Archival Responsibilities}

Survey responses from both groups, dual archivist/librarians and archivists without library responsibilities, reveal that it is common for academic archivists to have a wide variety of responsibilities. Respondents identified these by selecting from a list of archival duties for which they have responsibility, including activities they supervise but do not necessarily perform.

While the same percentage of each group identifies responsibility for archival description, a much higher percentage of the dual archivist/librarians group indicates responsibility for almost every other category of archival work including grant writing, disaster preparedness, archival instruction, conservation, metadata creation, archival administration, digitization, exhibits creation, and outreach than the comparison group members (see table 1 ). There is also a sizeable difference in the percentage of dual archivist/librarians with responsibility for the acquisition of archival materials, website development and maintenance, oral history, archival reference, creation or maintenance of collection management software, writing policies and procedures, monitoring onsite researchers, records management, archival appraisal, accessioning, supervision of staff or student workers, and arrangement of archival materials (see table 1).

In other words, the dual archivist/ librarians have a broader assortment of archival duties than the archivists without library duties. This does not necessarily imply more work - simply a greater variety of responsibilities within or related to archives.

\section{Nonarchival, Nonlibrary Responsibilities}

Survey respondents were also asked to select from a list of nonarchival duties for which they are responsible, again including activities they supervise (see Appendix, Question 21). The list included options that have been designated library responsibilities for this study; these are addressed specifically in the next section. ${ }^{36}$ Items designated " nonarchival" but not specifically library duties include teaching credit courses, preservation of nonarchival materials, and digital initiative responsibilities beyond the archives. A large percentage of both groups indicate responsibility for these nonarchival, nonlibrary duties. Once again, however, a higher percentage of dual archivist/librarians identify these nonarchival, nonlibrary activities as among their responsibilities (see figure 1). 


\begin{tabular}{|c|c|c|c|}
\hline \multicolumn{4}{|c|}{$\begin{array}{c}\text { TABLE } 1 \\
\text { Archival Responsibilities }\end{array}$} \\
\hline Responsibilities & $\begin{array}{c}\text { Dual } \\
\text { Archivist/ } \\
\text { Librarians } \\
\end{array}$ & $\begin{array}{c}\text { Archivist } \\
\text { without Library } \\
\text { Responsibilities }\end{array}$ & Difference \\
\hline Grant writing & $59 \%$ & $37 \%$ & $22 \%$ \\
\hline Disaster preparedness & $64 \%$ & $47 \%$ & $17 \%$ \\
\hline $\begin{array}{l}\text { Instruction sessions for archives (group or } \\
\text { individual) }\end{array}$ & $80 \%$ & $65 \%$ & $15 \%$ \\
\hline Conservation of archival materials & $68 \%$ & $54 \%$ & $14 \%$ \\
\hline $\begin{array}{l}\text { Creating metadata for digitized archival } \\
\text { materials }\end{array}$ & $73 \%$ & $61 \%$ & $12 \%$ \\
\hline $\begin{array}{l}\text { Archival administration (managing archival } \\
\text { programs) }\end{array}$ & $70 \%$ & $59 \%$ & $11 \%$ \\
\hline Digitization of archival materials & $81 \%$ & $70 \%$ & $11 \%$ \\
\hline Creating exhibits with archival materials & $86 \%$ & $76 \%$ & $10 \%$ \\
\hline Outreach, advocacy, or promotion & $87 \%$ & $77 \%$ & $10 \%$ \\
\hline Acquisition of archival materials & $87 \%$ & $78 \%$ & $9 \%$ \\
\hline $\begin{array}{l}\text { Website development/maintenance for } \\
\text { archives }\end{array}$ & $64 \%$ & $55 \%$ & $9 \%$ \\
\hline Oral history & $39 \%$ & $31 \%$ & $8 \%$ \\
\hline Archival reference & $94 \%$ & $87 \%$ & $7 \%$ \\
\hline $\begin{array}{l}\text { Creation/maintenance of collection } \\
\text { management software for archives }\end{array}$ & $55 \%$ & $48 \%$ & $7 \%$ \\
\hline Writing policies and procedures & $87 \%$ & $80 \%$ & $7 \%$ \\
\hline Monitoring on-site researchers & $84 \%$ & $78 \%$ & $6 \%$ \\
\hline Records management & $47 \%$ & $41 \%$ & $6 \%$ \\
\hline $\begin{array}{l}\text { Identification of archival materials } \\
\text { (appraisal) }\end{array}$ & $85 \%$ & $80 \%$ & $5 \%$ \\
\hline Accessioning archival materials & $89 \%$ & $86 \%$ & $3 \%$ \\
\hline Supervision of staff or student workers & $90 \%$ & $88 \%$ & $2 \%$ \\
\hline $\begin{array}{l}\text { Arrangement and housing of archival } \\
\text { materials }\end{array}$ & $96 \%$ & $95 \%$ & $1 \%$ \\
\hline Description/cataloging of archival materials & $85 \%$ & $85 \%$ & $0 \%$ \\
\hline Offsite storage & $28 \%$ & $40 \%$ & $-12 \%$ \\
\hline
\end{tabular}

Clearly, in addition to their wide range of archival responsibilities, the dual archivist/librarians are also heavily involved with nonlibrarian, nonarchival activities. As a group, they are more diversified in their duties within and beyond the archives and are more likely to be engaged in nonarchival activities than the comparison group. Yet this still does not complete the picture for dual archivist/librarians.

\section{Library Responsibilities}

The five nonarchival duties designated as library responsibilities for this study are special collections librarianship, library 


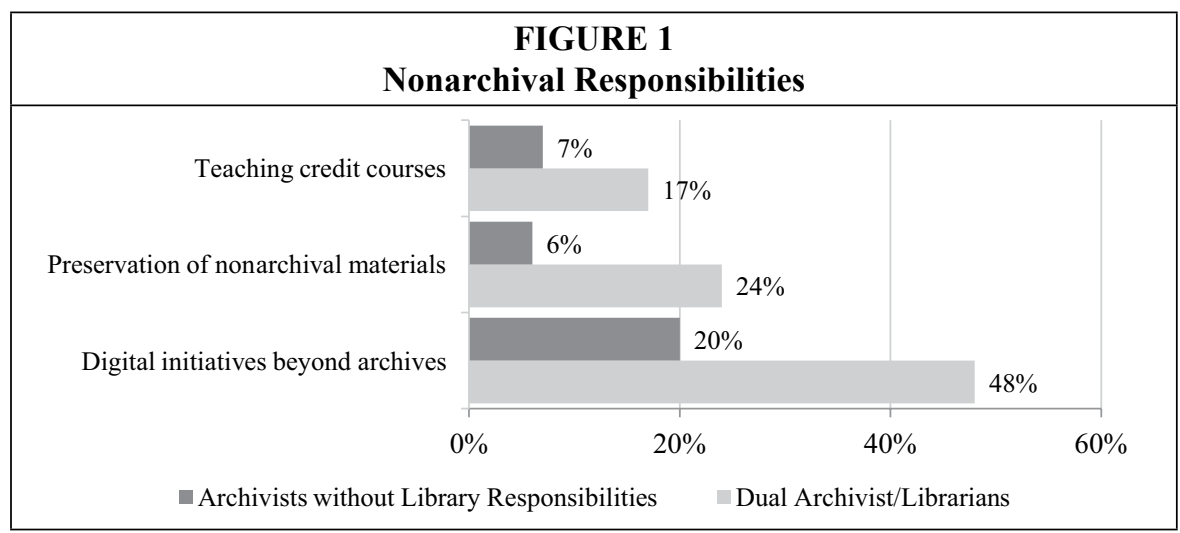

reference, library instruction, library collection development, and library liaison to teaching departments. Again, these library responsibilities are what set the dual archivist/librarians apart from their counterparts in this study.

Special collections librarianship is the most common library responsibility cited by dual archivist/librarians, with $64 \%$ of this group identifying it as part of their duties (see figure 2). This is not at all surprising as special collections librarianship commonly encompasses books and manuscripts. These information professionals have traditionally had a foot in both worlds.

More interesting is the fact that over 50 percent of the dual archivist/librarians identify library instruction and library reference as being within their realm of responsibility. Additionally, 47 percent either perform library collection development and/or serve as liaisons to teaching departments (see figure 2). ${ }^{37}$

When one considers that dual archivist/librarians are more involved in every facet of archival responsibility and are also very heavily engaged in other nonarchival responsibilities such as digital initiative responsibilities beyond the archives, preservation of nonarchival materials, and teaching credit courses, the assortment of library responsibilities within their job responsibilities adds enormously to the diversification of duties for this group. It is no wonder that these dual archivist/librarians mention challenges in fulfilling all their duties as well as they would like.

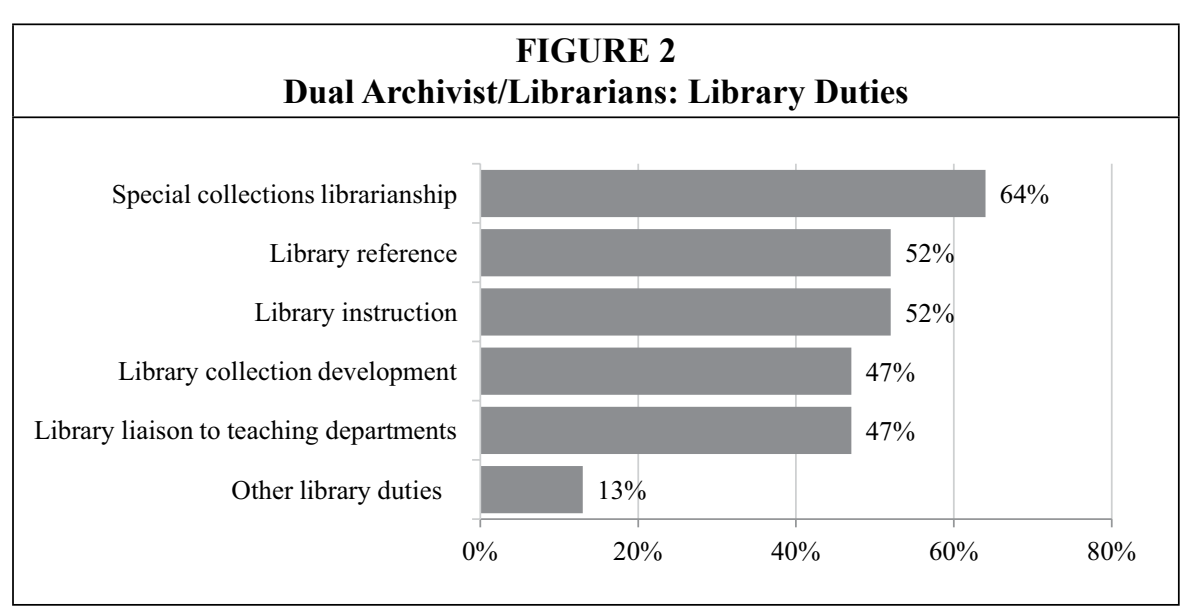




\section{Research Findings: Qualitative Analysis of Challenges and Benefits Questions}

The authors' survey included two openended questions about the respondents' perceptions of the principal challenges and benefits of having nonarchival responsibilities (see Appendix, Questions 23 and 24). This section focuses on the dual archivist/ librarians' responses to these two questions, specifically comments regarding library responsibilities. Respondents were encouraged to answer candidly, and the vast majority of survey takers did respond to these two optional questions, many at great length. The dual archivist/librarians answered more of the optional questions, and their responses were lengthier than the comparison group's. The dual archivist/ librarians' comments revealed more than their answers to targeted questions and expressed both enthusiasm and anxiety about the challenges and benefits associated with having nonarchival responsibilities. Responses were analyzed using a tagging methodology, and it is worth noting that many responses referred to benefits and challenges in terms of fulfillment of institutional mission. ${ }^{38}$

\section{Dual Archivist/Librarians'Challenges of Having Nonarchival Responsibilities}

"Time" was overwhelmingly the highest occurring response to the open-ended question: "What do you perceive as the principal challenges of having nonarchival responsibilities?" (See Appendix, Question 24) This was a response given by the majority of dual archivist/librarians (65\%) (see figure 3). Representative comments follow:

I often feel pulled in too many directions, with not enough time to do any one job well. As a liaison to academic departments I have been fairly successful raising the library's profile among faculty and students in my departments. One of my long term goals is to integrate the collection I manage into the curriculum there are several programs on campus it is relevant to. But I don't have the time to really focus on this goal.

It takes away from the time I have to manage the archives, to process materials, and to work with archives patrons.

There's simply not enough time to do everything that needs to be done in the Archives/Special Collections as well as my other library-related responsibilities. I usually feel like I'm putting out fires all week, and

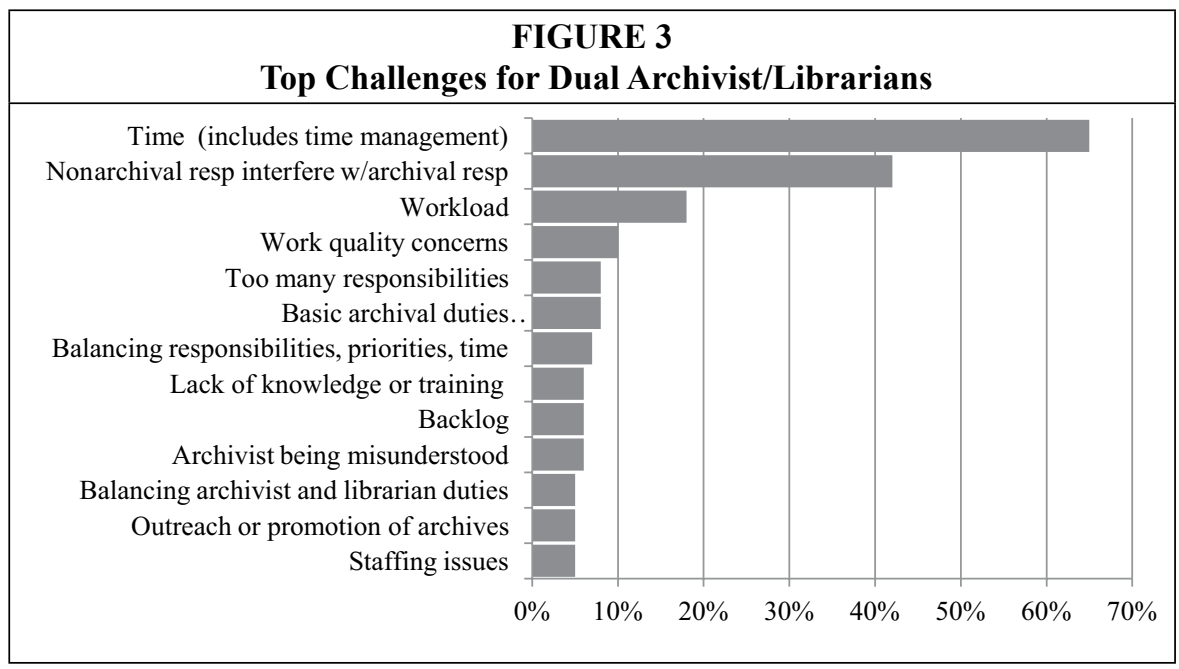


many things slip to the bottom of my priority list when they really deserve to be higher on the list.

"Nonarchival responsibilities interfere with archival responsibilities" ranked second as a response of dual archivist/ librarians to the challenges question, making up 42 percent of responses (see figure 3). For example:

My work as a reference librarian keeps me out of the Archives a lot.

My liaison responsibilities take up a significant amount of time, which I certainly could use for archival responsibilities.

These responsibilities are seen as "librarian" responsibilities but archival responsibilities are not seen as a responsibility of other librarians. In short, if the library is short-handed in reference, collection development, administration, etc., librarians will step into these roles; however if the archives and special collections is short-handed, the response is generally to close the department or limit access.

"Workload" is cited by $18 \%$ of dual archivist/librarians and ranked third as a challenge. Other issues cited by dual archivist/librarians include work quality concerns $(10 \%)$, too many responsibilities (8\%), accomplishing basic archival duties (accessioning, arranging, describing, and processing) $(8 \%)$, balancing responsibilities, priorities, and time (7\%), lack of training or knowledge $(6 \%)$, backlog $(6 \%)$, archivists being misunderstood (often by librarians) (6\%), balancing archivist and librarian responsibilities (5\%), outreach and promotion of archives (5\%), and staffing issues (5\%) (see figure 3). Examples of additional comments:

The more I do outside the archives, the less happens inside and the backlog grows. Since my staff was cut last summer, I've had to reduce services in the archive.

I look like an idiot sometimes because I have no training or job experience for some of my nonarchival responsibilities such as collection development.

My graduate education prepared me to be an archivist, not a rare book specialist or a library cataloger. I've never received any formal training in these areas, and I often find it challenging to find time to learn on my own.

I also feel that [liaison responsibilities are] an additional area of expertise that I need to keep up. I would feel more efficient if my energies could be more focused on special collections, and keeping up with all of the trends there. I see myself as a liaison to all departments as the special collections librarian.

\section{Dual Archivist/Librarians' Benefits of Having Nonarchival Responsibilities}

The most frequently occurring benefit to having nonarchival responsibilities cited by dual archivist/librarians relates to outreach or promotion (30\%) (see figure 4). This includes responses mentioning increased or raised profile or visibility and advocacy. Representative comments:

Being the liaison and doing collection development for the history department and having teaching responsibilities allows me to do outreach on a level that would not be otherwise possible.

Serving at the reference desk gives me valuable insight as to what is actually going on at my university in terms of research needs. Additionally, being the liaison and doing collection development for the history department and having 


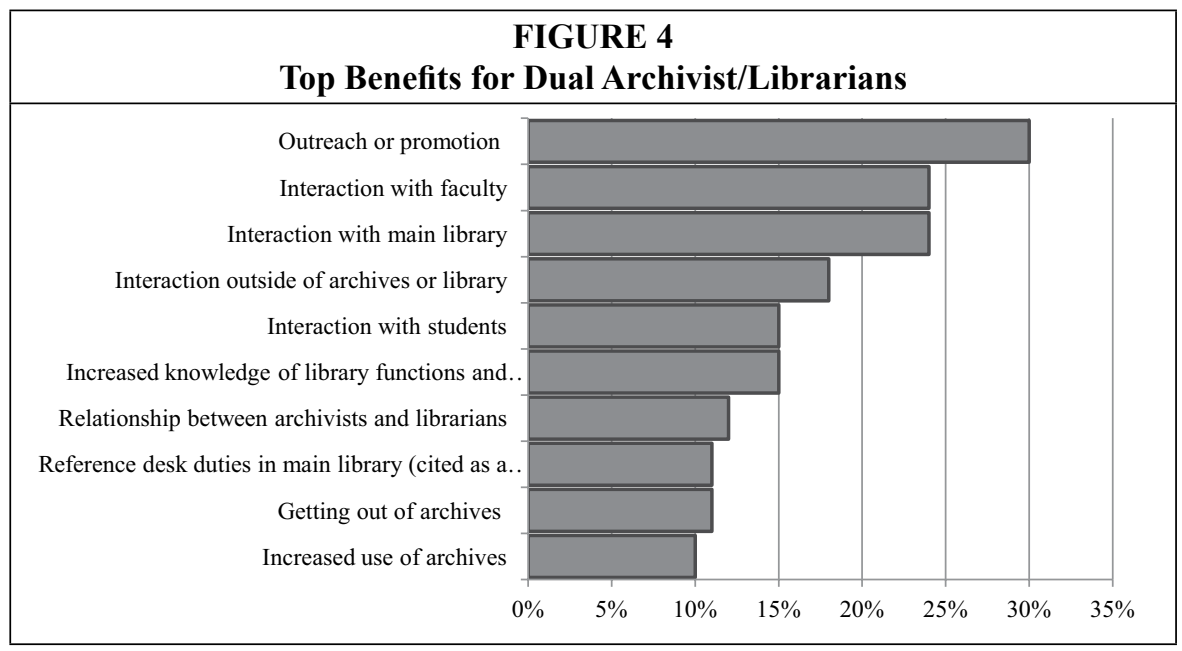

teaching responsibilities allows me to do outreach on a level that would not be otherwise possible.

We are able to keep in touch with what is going on in the rest of the library as well as to share what we are doing in a way that helps others appreciate the importance of the separate but related role of the archives.

The second highest benefits cited include both interaction with faculty (24\%) and interaction with main library (24\%) (see figure 4). Comments:

Interaction with other librarians and with members of the faculty ... has always been beneficial, providing opportunities for outreach and education about the archives, as well as opportunities for me to learn about other campus constituencies.

I also have liaison responsibilities to a teaching department. The principal benefit of these responsibilities are the opportunity to meet more faculty, who may also have an interest in using special collections, and also to work closely with the other librarians and continue to raise their awareness of special collections as well.
Having an opportunity to interact with other library staff; having an understanding of the issues/ problems/concerns that arise in our library.

Other benefits cited by dual archivist/ librarians to having nonarchival responsibilities include interaction outside archives or library $(18 \%)$, interaction with students $(15 \%)$, increased knowledge of library functions and activities (15\%), relationship between archivists and librarians $(12 \%)$, reference desk duties in main library (11\%), getting out of archives $(11 \%)$, and increased use of archives $(10 \%)$ (see figure 4). Many responses include a combination of benefits:

I also find that my dual role as an archivist and library liaison allows me to provide better reference and instructional service, as I have a stronger sense of the "big picture." Having multiple responsibilities also allows me to enjoy more variety in my day-to-day tasks and projects and provides me with opportunities to get to know more people within the campus community.

I get to interact with the student and faculty population more than I 
would holed up in the archives. I'm also able to work with the librarians to assist in their instruction and the general direction of the library so that it also includes the archives as an integral part of the whole.

My work as a liaison has allowed me opportunities to get to know teaching faculty and get them and their students interested in the Archives. Archives usage has increased as a result.

I feel like I get to see two sides of research like no one else because I am both a librarian and an archivist. When I'm wearing my librarian hat, I help students use mostly secondary sources. But, even as a librarian, I can't help but be an archivist and steer students towards primary content as well. I am fortunate to have a very holistic view of research incorporating primary, secondary, and tertiary sources. I love what I do.

These comments represent a mere sampling of the 380 total responses to the two questions about benefits and challenges. The authors are grateful to all survey respondents for their frank responses to these questions.

\section{Further Research}

The results of our survey reveal some interesting issues for dual archivist/ librarians that bear further exploration. The survey was sent to archives listservs; however, the study revealed that information professionals who responded might be archivists with library responsibilities or librarians with archival responsibilities. Survey respondents had only to be engaged in archival work to qualify for the survey. Further research targeting librarians with archival duties is therefore indicated.

The information professionals in our study remarked about lacking adequate training and skills for library work. This raises the question: How are information professionals who are trained as archivists managing their duties and training requirements when library responsibilities are part of their workload? And, conversely, how are information professionals who are trained as librarians managing their duties and training requirements when archival responsibilities are part of their workload?

Broader questions raised include the effects of job diversification on dual archivist/librarians. Comments from this group reveal a high level of stress associated with both the number and the variety of responsibilities and the information professionals' perceived job effectiveness.

The theme of exploding workload came up repeatedly in the dual archivist/ librarians' comments. It is important for information professionals in academia to understand the roles and responsibilities of colleagues in the archives. Administrators should also be aware of how library and archives jobs are changing-sometimes subtly, sometimes dramatically - so they can effectively manage increasingly limited resources at their institutions. It is hoped that this study will be useful in these two regards, and additional research on the roles of dual archivist/ librarians will follow.

The need to preserve the cultural record is greater than ever as formats expand and morph, not just electronic records but audiovisual materials and other traditional records. Many survey respondents with both library and archival responsibilities expressed regret that they were not doing more to capture, preserve, and make their institutional histories available. The most urgent question seems to be: Can these information professionals be successful in fulfilling their institutional missions while juggling so many responsibilities?

\section{Conclusion}

College and university archivists in the United States today face increasingly expansive workloads. Information professionals, both librarians and archivists, face 
unprecedented changes and challenges. This study of dual archivist/librarians suggests that having both library and archival responsibilities results in a balancing act that is difficult to maintain.

To some extent, the inclusion of nonarchival activities including library duties benefits the archives and the parent institutions by breaking down barriers with faculty and students and among information professionals and by educating the wider campus community about the benefits of archival programs. However, this study suggests that the challenges rival the benefits for dual archivist/librarians. Survey respondents voiced concerns about performing all of their work competently. They expressed anxiety both about the quality and the quantity of their work because of the diversity of responsibilities. Professional effectiveness across the broad spectrum of duties is called into question, and this will almost certainly have an effect on the fulfillment of institutional missions. In times of reduced budgets, it may be difficult to justify allocating more staff to archives. How then to balance the benefits and challenges evidenced in this study? With academic archivists pulled in so many directions, one has to wonder to what extent their archival work is being jeopardized, and what part of our cultural record will be lost as a result.

\section{Appendix Survey Questions}

1. Are you employed at an American college or university and do you have responsibilities of an archivist/manuscript curator*?

Regardless of your job title, if you have the responsibilities of an archivist/manuscript curator including any of those defined below, please answer YES for this question.

*The responsibilities of an archivist include "1. appraising, acquiring, arranging, describing, preserving, and providing access to records of enduring value, according to the principles of provenance, original order, and collective control to protect the materials' authenticity and context. - 2. management and oversight of an archival repository or of records of enduring value"

The responsibilities of a manuscript curator include "appraising, acquiring, arranging, describing, preserving, and providing access to a collection of original documents."

The responsibilities of archivist and manuscript curator are adapted from "archivist" and "manuscript curator" in Richard Pearce-Moses, A Glossary of Archival and Records Terminology (www.archivists.org/glossary/)

In the same glossary cited above, Pearce-Moses defines a manuscript curator as "an archivist" (www.archivists.org/glossary/term_details.asp? DefinitionKey=883). Pearce-Moses adds: "The use of 'archivist' to describe a manuscript curator is common in the United States."

For the purposes of this survey, the term "archivist" should be understood to describe a "manuscript curator," and "archival responsibilities" should be understood to describe the responsibilities of either an archivist or a manuscript curator.

2. Total number of people employed as archivists at your institution:

$\square$ Full time $\square$ Part time 
3. Does your institution have more than one repository of archival materials?

$\square$ Yes $\square$ No $\square$ Don't know/not sure

4. Total number of people employed as archivists in your department:

$\square$ Full-time $\square$ Part-time

5. Total number of people employed as archivists and librarians in your department: $\square$ Full-time $\square$ Part-time

6. Your department is most directly under the jurisdiction of the:

$\square$ Office of the Provost or Chief Academic Officer

$\square$ Office of the President

$\square$ Office of Information Technology

$\square$ Other (please specify)

7. Indicate the size for your university (based on Carnegie Foundation's size categories below):

S2: Small two-year.

${ }^{*}$ FTE enrollment of 500-1,999 students at these associate's degree granting institutions.

$\square$ M2: Medium two-year.

*FTE enrollment of 2,000-4,999 students at these associate's degree granting institutions.

$\square$ L2: Large two-year.

${ }^{*} F T E$ enrollment of 5,000-9,999 students at these associate's degree granting institutions.

$\square$ VL2: Very large two-year.

*FTE enrollment of at least 10,000 students at these associate's degree granting institutions.

$\square$ VS4: Very small four-year.

${ }^{*}$ FTE enrollment of fewer than 1,000 degree-seeking students at these bachelor's degree granting institutions.

S4: Small four-year.

${ }^{*}$ FTE enrollment of 1,000-2,999 degree-seeking students at these bachelor's degree granting institutions.

$\square$ M4: Medium four-year.

*FTE enrollment of 3,000-9,999 degree-seeking students at these bachelor's degree granting institutions. L4: Large four-year.

${ }^{*}$ FTE enrollment of at least 10,000 degree-seeking students at these bachelor's degree granting institutions.

8. Your job title:

9. Is this a tenure-track position?

Y Yes $\square$ No

Comments (optional)

10. How do you describe your primary role?

Archivist $\square$ Manuscript curator

$\square$ Project archivist $\square$ Special collections librarian $\square$ Manuscripts librarian

Archivist/special collections librarian

Archivist/special collections librarian/librarian in another area(s)

$\square$ Both archivist and librarian in another area(s), but not special collections librarian

$\square$ Librarian $\square$ Historian $\square$ Oral historian $\square$ Records manager

$\square$ Records manager/archivist $\square$ Other (please specify)

11. What do your archival responsibilities include? Include activities that you supervise. Check all that apply: 
Writing policies and procedures

$\square$ Monitoring onsite researchers

$\square$ Oral history

$\square$ Disaster preparedness

Archival reference

Digitization of archival materials

$\square$ Creating or maintaining an institutional repository

$\square$ Identification of archival materials (appraisal)

Instruction sessions for archives (group or individual)

$\square$ Conservation of archival materials

Acquisition of archival materials

$\square$ Institutional repository

Archival administration (managing archival programs)

Arrangement and housing of archival materials

Description/cataloging of archival materials. May include creation of EAD finding aids

Creation/maintenance of collection management software for archives (examples:

ARCHON, Archivists Toolkit, PastPerfect, Access or an in-house system)

$\square$ Outreach, advocacy, or promotion

$\square$ De-accessioning archival materials

$\square$ Supervision of staff or student workers

$\square$ Creating metadata for digitized archival materials

$\square$ Grant writing

$\square$ Offsite storage

$\square$ Creating exhibits with archival materials

Web site development/maintenance for archives

$\square$ Records management

Accessioning archival materials

$\square$ Other (please specify)

Note: The authors inadvertently asked about involvement with institutional repository (IR) twice in the question above. Since we asked about IR involvement (questions 16 and 17) and records management involvement (questions 14 and 15) in more detail in those questions, we did not analyze the data for these responses in this question.

12. During a typical week, approximately what percentage of your work hours is spent performing archival responsibilities (including archival administration/ management responsibilities)?

口 $0 \%-20 \%$ 口 $21 \%-40 \%$

$41 \%-60 \%$

$61 \%-80 \%$

$\square 81 \%-100 \%$

Comments (optional):

13. During a typical week, approximately what percentage of the time indicated in the previous question is spent on administrative or management duties?

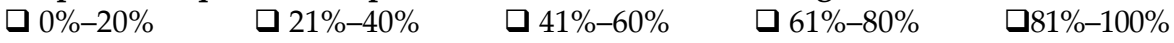

Comments (optional)

14. Does your institution have a records management program?

Yes $\square$ No (will skip to question number 16)

Don't know/not sure (will skip to question number 16)

Comments (optional):

Records Management is defined as "The systematic and administrative control of records throughout their life cycle to ensure efficiency and economy in their creation, use, handling, control, maintenance, 
and disposition" (Richard Pearce-Moses, A Glossary of Archival and Records Terminology, www. archivists.org/glossary/term_details.

15. To what extent are you involved with records management at your institution?

$\square$ I am the person primarily responsible for records management at my institution

I share responsibility for records management at my institution

I am minimally involved in records management at my institution

I am not involved in records management at all at my institution

Comments (optional):

16. Does your institution have an institutional repository?

$\square$ Yes $\square$ No (will skip to question number 18)

Don't know/not sure (will skip to question number 18)

Comments (optional):

An institutional repository is defined as "Software and associated rules used to capture, structure, provide access to, and preserve digital materials produced by an organization or community" (Richard Pearce-Moses, A Glossary of Archival and Records Terminology, www.archivists.org/glossary/term_details. asp?DefinitionKey=2713).

Note: Institutional repositories are commonly created with software (such as DSpace and Fedora).

17. To what extent are you involved with the creation or maintenance of an institutional repository?

I am the person primarily responsible for the institutional repository

I share responsibility for the institutional repository

$\square$ I am minimally involved with the institutional repository

I am not involved with the institutional repository

Comments (optional):

18. Is research and/or scholarly writing a requirement for your position?

$\square$ Yes $\square$ No (will skip to question number 20)

Comments (optional):

19. On average, how many hours per week (rounded to a whole number) do you spend doing research and/or scholarly writing?

20. Do you have nonarchival responsibilities?

$\square$ Yes $\square$ No (will skip to question number 25)

Comments (optional):

21. Check all assigned nonarchival responsibilities that apply:

$\square$ Special collections librarianship $\square$ Library liaison to teaching departments

$\square$ Library instruction $\square$ Library reference $\quad \square$ Teaching for course credit

$\square$ Preservation of nonarchival materials $\quad \square$ Library collection development

$\square$ Digital initiatives $\square$ Committee work (Library)

$\square$ Committee work (College/University) $\quad$ Other (please specify)

22. What percentage of your time is spent performing nonarchival responsibilities? $\square 0 \%-20 \% \square \quad \square 21 \%-40 \% \quad \square+1 \%-60 \% \quad \square 61 \%-80 \% \quad \square 81 \%-100 \%$ Comments (optional) 


\author{
23. What do you perceive as the principal benefits of having nonarchival respon- \\ sibilities?
}
24. What do you perceive as the principal challenges of having nonarchival respon- sibilities?

\title{
25. Do you have any additional comments about the role of contemporary archivists at American colleges and universities or about this survey?
}

\section{Notes}

1. From our initial survey pool, we included only respondents who answered "yes" to this question: "Are you employed at an American college or university and do you have responsibilities of an archivist/manuscript curator"?"

To encourage information professionals with the responsibilities of an archivist or a manuscript curator to respond to the survey, the authors emphasized that term "archivist" should be understood to describe a "manuscript curator," and "archival responsibilities" should be understood to describe the responsibilities of either an archivist or a manuscript curator.

To define these responsibilities, the authors adapted definitions of these two closely related job titles from Richard Pearce-Moses's, A Glossary of Archival and Records Terminology (see survey question one in Appendix B).

2. Respondents who mentioned that they have library responsibilities in the "Other" choice of this question were also included in the dual archivist/librarian group.

3. Nicholas C. Burckel and J. Frank Cook, "A Profile of College and University Archives in the United States," American Archivist 45 (fall 1982): 410-28; Ruth W. Helmuth, "Startling Facts Revealed by the C \& U Survey, Presented Before the College and University Archives Committee at the 36th Annual Meeting of the Society of American Archivists, Columbus, Ohio, Oct. 31-Nov. 3, 1972" (Unpublished). Burckel also surveyed archivist colleagues in 2004 about time spent on traditional archival functions, records management, and institutional repositories: Personal correspondence from Burckel, Nov. 2009, Society of American Archivists, $A^{*}$ Census: Archival Census $\mathcal{E}$ Education Needs Survey in the United States (May 2004), available online at www.archivists. org/a-census [accessed 8/31/2009].

4. Frank Boles, "But a Thin Veil of Paper," American Archivist 73 (2010): 19-25.

5. Christopher J. Prom and Ellen D. Swain, Preface to College and University Archives: Readings in Theory and Practice (Chicago: Society of American Archivists Press, 2008), ix. viii.

6. Prom and Swain, Preface to College and University Archives: Readings in Theory and Practice,

7. Christopher J. Prom, "Optimum Access? Processing in College and University Archives," in College and University Archives: Readings in Theory and Practice, eds. Christopher J. Prom and Ellen D. Swain (Chicago: Society of American Archivists Press, 2008), 178.

8. Mark A. Greene and Dennis Meissner, "More Product, Less Process: Revamping Traditional Archival Processing," American Archivist 68 (2005): 208-63; Matt Gorzalski, "Minimal Processing: Its Context and Influence in the Archival Community," Journal of Archival Organization 6 (2008): 186-200; Donna E. McCrea, "Getting More for Less: Testing a New Processing Model at the University of Montana," American Archivist 69 (2006): 284-93; Jeannette Mercer Sabre and Susan Hamburger, "A Case for Item-level Indexing: The Kenneth Burke Papers at The Pennsylvania State University," Journal of Archival Organization 6 (2008): 24-46; Carl Van Ness, "Much Ado about Paper Clips: 'More Product, Less Process' and the Modern Manuscript Repository," American Archivist 73 (2010): 129-45; Christine Weideman, "Accessioning as Processing," American Archivist 69 (2006): 274-83.

9. Jennie A. Levine, Jennifer Evans, and Amit Kumar, "Taming the 'Beast': An Archival Management System Based on EAD," Journal of Archival Organization 4:3/4 (2006): 63-98; Clay Redding, "Reengineering Finding Aids Revisited: Current Archival Descriptive Practice and Its Effect on EAD Implementation," Journal of Archival Organization 1, no. 3 (2002): 35-50.

10. Helen Tibbo, "The Impact of Information Technology on Academic Archives in the Twentyfirst Century," in College and University Archives: Readings in Theory and Practice, eds. Christopher J. Prom and Ellen D. Swain (Chicago: Society of American Archivists Press, 2008), 28. Richard J. Cox, "The Academic Archives of the Future," Educause Review 43 (2008): 10-11.

11. New Skills for A Digital Era, eds. Richard Pearce-Moses and Susan E. Davis, a colloquium 
sponsored by National Archives and Records Administration, Society of American Archivists, Arizona State Library, Archives and Public Records, May 31-June 2, 2006, available online at www. archivists.org/publications/proceedings/NewSkillsForADigitalEra.pdf [accessed December 2010]; Elizabeth H. Dow, Electronic Records in the Manuscript Repository (Lanham, MD: Scarecrow Press, 2009); William Saffady, Managing Electronic Records (4th ed.) (Lenexa, Kan.: ARMA International and Neal-Schuman, 2009); Luciana Duranti, Terence M. Eastwood, and Heather MacNeil, Preservation of the Integrity of Electronic Records (Dordrecht; Boston: Kluwer Academic, 2002); Thirty Years of Electronic Records, ed. Bruce I. Ambacher (Lanham, MD: Scarecrow Press, 2003).

12. James Lowrey and Matt Blessing, "An Anniversary Opportunity: Digitization of Student Yearbooks," Microform \& Imaging Review 35 (2006): 129-33; David Free, "Marquette University Digitizes Van Vechten," College E Research Libraries News 70 (2009): 209; Christopher Raab, "Digitizing Pennsylvania German Fraktur using DSpace," Microform E Imaging Review 37 (2008): 158-62; Michael J. Paulus Jr., "Blogging for the Record: A Study of Blogging from an Archival Point of View," Journal of Archival Organization 4 (2006): 31-41.

13. Ellen D. Swain, "Remembering Alma Mater: Oral History and the Documentation of Student Culture, with a new Afterward: Reflections on Oral History in Academia and the Digital Age," in College and University Archives: Readings in Theory and Practice, ed. Christopher J. Prom and Ellen D. Swain (Chicago: Society of American Archivists Press, 2008), 71-95; Michele Christian, "Documenting Student Life: The Use of Oral Histories in University Archives," Archival Issues: Journal of the Midwest Archives Conference 27 (2002): 111-24.

14. MacKenzie Smith, "Exploring Variety in Digital Collections and the Implications for Digital Preservation," Library Trends 54 (2005): 6-15; Jeffrey Young, "'Superarchives' Could Hold All Scholarly Output," Chronicle of Higher Education 48 (2002): A29-30; Elizabeth Yakel, Soo Young Rieh, Beth St. Jean, Karen Markey, and Jihyun Kim, "Institutional Repositories and the Institutional Repository: College and University Archives and Special Collections in an Era of Change," American Archivist 71 (2008): 323-49; Robert P. Spindler, "Electronic Publishing and Institutional Memory," in College and University Archives: Readings in Theory and Practice, eds. Christopher J. Prom and Ellen D. Swain (Chicago: Society of American Archivists Press, 2008), 65-68.

15. Nancy M. Kunde, "Reframing Records Management in Colleges and Universities," in College and University Archives: Readings in Theory and Practice, eds. Christopher J. Prom and Ellen D. Swain (Chicago: Society of American Archivists Press, 2008), 208.

16. Elizabeth Yakel, Young Rieh Soo, Beth St. Jean, Karen Markey, and Jihyun Kim. "Institutional Repositories and the Institutional Repository: College and University Archives and Special Collections in an Era of Change," American Archivist 71 (2008): 323-49; Robert P. Spindler, "Electronic Publishing and Institutional Memory," in College and University Archives: Readings in Theory and Practice, eds. Christopher J. Prom and Ellen D. Swain (Chicago: Society of American Archivists Press, 2008), 65-68.

17. S. Victor Fleischer and Mark J. Heppner, "Disaster Planning for Libraries and Archives: What You Need to Know and How to Do It," Library E Archival Security 22 (2009): 125-40.

18. Michelle Riggs, "The Correlation of Archival Education and Job Requirements since the Advent of Encoded Archival Description," Journal of Archival Organization 3 (2005): 61-79; Richard Szary, "Encoded Finding Aids as a Transforming Technology in Archival Reference Service," in College and University Archives: Readings in Theory and Practice, eds. Christopher J. Prom and Ellen D. Swain (Chicago: Society of American Archivists Press, 2008), 245-59; Janice E. Ruth, "Education the Reference Archivist," American Archivist 51 (1988): 266-77; Frances O'Donnell, "Reference Service in an Academic Archives," Journal of Academic Librarianship 26 (2000): 110-18.

19. John R. Thelin, "Archives and the Cure for Institutional Amnesia: College and University Saga as Part of the Campus Memory," Journal of Archival Organization 7 (2009): 4-15; Kathryn M. Neal, "Giving It More than the Old College Try: Documenting Diverse Populations in College and University Archive," in College and University Archives: Readings in Theory and Practice. eds. Christopher J. Prom and Ellen D. Swain (Chicago: Society of American Archivists Press, 2008), 97-116.

20. Sandra Roff, "Archives, Documents, and Hidden History: A Course to Teach Undergraduates the Thrill of Historical Discovery Real and Virtual," History Teacher 40 (2007): 551-58; Elizabeth Stephenson and Patti Schifter Caravello, "Incorporating Data Literacy into Undergraduate Information Literacy Programs in the Social Sciences," Reference Services Review 35 (2007): 525-40; Doris J. Malkmus, "Primary Source Research and the Undergraduate: A Transforming Landscape," Journal of Archival Organization 6 (2008): 47-70; Laura Clark Brown, "Chapel Hill Diarist: The Evolution of a Theory and the Practice of Immersion in Primary Sources," Journal for the Society of North Carolina Archivists 6 (2009): 5-25.

21. Diana R. Sanderson, "No Task Is Unimportant: Working with High School Students in the Archives," Journal for the Society of North Carolina Archivists 6 (2009): 92-98; Julia Hendry, "Primary Sources in K-12 Education: Opportunities for Archives," American Archivist 70 (2007): 114-29; 
Tibbo, “The Impact of Information Technology," 36.

22. Janet C. Olson, "Teaching with Archives, Teaching about Archives," Journal for the Society of North Carolina Archivists 6 (2009): 86-91.

23. Elizabeth Konzak and Dwain P. Teague, "Reconnect with Your Alumni and Connect to Donors," Technical Services Quarterly 26 (2009): 217-25.

24. Tamar Chute, "Perspective on Outreach at College and University Archives," College and University Archives: Readings in Theory and Practice, eds. Christopher J. Prom and Ellen D. Swain (Chicago: Society of American Archivists Press, 2008), 153.

25. The spring 2007 issue of $R B M$ consists primarily of articles pertaining to the convergence of special collections library and archives roles. This issue followed the 2006 RBMS preconference "Libraries, Archives, and Museums in the Twenty-First Century: Intersecting Missions, Converging Futures" and featured articles originally presented as papers from the preconference.

26. Christian Dupont, "Libraries, Archives, and Museums in the Twenty-First Century: Intersecting Missions, Converging Futures?" RBM 8 (2007): 13-19; Bruce Whiteman, “Cooperative Collection Building: A Response to Gerald Beasley," RBM 8 (2007): 29-34.

27. Beverly P. Lynch, "Professional Associations and Library Education," RBM 11 (2010): 32-46; Deirdre C. Stam, "Bridge That Gap! Education and Special Collections," RBM 7 (2006): 16-30; Jackie Dooley, "Ten Commandments for Special Collections Librarians in the Digital Age," RBM 10 (2009): 51-59; William E. Landis, "Personas and Archetypes: Envisioning the 21st-Century Special Collections Professional," RBM 7 (2006): 40-48.

28. Ann Wheeler, "A Cataloger and an Archivist: Katherine Ryner and St. Mary's College of Maryland," College \& Research Libraries News 69 (2008): 390-91.

29. Janie M. Mathews and Harold Pardue, "The Presence of IT Skill Sets in Librarian Position Announcements," College \& Research Libraries 70 (2009): 250-57; Riggs, "The Correlation of Archival Education and Job Requirements," 61-79; Richard J. Cox, "Employing Records Professionals in the Information Age: A Research Study," Information Management Journal 34 (2000): 18-33.

30. Tom Nesmith, "Professional Education in the Most Expansive Sense: What Will the Archivist Need to Know in the Twenty-first Century?" Archivaria 42 (1996): 89-94.

31. Jeannette Bastian and Elizabeth Yakel, "Towards the Development of an Archival Core Curriculum: The United States and Canada," Archival Science 6 (2006): 133-50; Richard J. Cox, Elizabeth Yakel, David Wallace, and Jeannette Bastian, "Archival Education in North American Library and Information Science Schools," Library Quarterly 71 (2001): 141-94; Terry Eastwood, "Building Archival Knowledge and Skills in the Digital Age," Archival Science 6 (2006): 163-70; Frederic M. Miller, "The SAA as Sisyphus: Education since the 1960s," American Archivist 63 (2000): 224-36; Helen R. Tibbo, "A Vision of Archival Education at the Millennium," Journal of Education for Library and Information Science 38 (1997): 221-25.

32. R.C. Berner, "Archival Education and Training in the United States, 1937 to Present," Journal of Education for Librarianship 22 (1981): 3-19; Gerald F. Ham, Frank Boles, Gregory S. Hunter, and James M. O'Toole, "Is the Past Still Prologue? History and Archival Education," American Archivist 57 (1994): 718-29; William W. Hardesty, “'A Proper Function of Library Schools': T.R. Schellenberg's Archives Institute at the University of Texas, 1960," Libraries \& the Cultural Record 42 (2007): 129-50.

33. David Murrah, "Employer Expectations for Archivists: a Review of a 'Hybrid Profession'," Journal of Library Administration 11 (1989): 165-74.

34. IRB clearance was attained at the authors' respective institutions, and the survey was pretested by colleagues in both library and archives positions.

35. Follow-up requests for participation and reminders were sent to the A\&A list and five regional discussion lists.

36. The five nonarchival duties designated as library responsibilities for this study are special collections librarianship, library reference, library instruction, library collection development, and library liaison to teaching departments.

37. Other library duties identified by dual archivist/librarians include interlibrary loan, technical services, cataloging, government documents, serials, and bibliographic instruction.

38. All the percentages mentioned in the analysis of the benefits and challenges questions are based on the number of respondents to the questions; they are not percentages of the total survey group. A total of 89 percent of dual archivist/librarians and 45 percent of the archivists without library responsibilities responded to the challenges question. For the benefits question, 91 percent of the dual archivist/librarians and 46 percent of the archivists without library responsibilities responded. The average word count for each comment was higher for dual archivist/librarians. For the challenges question, dual archivist/librarians averaged 27 words per response and archivists without library responsibilities averaged 16 words per response. For the benefits question, the dual archivist/librarians averaged 40 words per response, and the archivists without library responsibilities averaged 25 words per response. 